\title{
Geochemical distribution of major and trace elements in agricultural soils of Castilla-La Mancha (central Spain): finding criteria for baselines and delimiting regional anomalies
}

\author{
Sandra Bravo ${ }^{1,2}$ • Efrén García-Ordiales ${ }^{3}$ - Francisco Jesús García-Navarro ${ }^{1,2}$. \\ José Ángel Amorós ${ }^{1,2}$. Caridad Pérez-de-los-Reyes ${ }^{1,2}$ - Raimundo Jiménez-Ballesta ${ }^{4}$. \\ José María Esbrí $^{2,5}$ • Eva María García-Noguero ${ }^{2,5}$ • Pablo Higueras ${ }^{2,5}$
}

Received: 17 April 2017 / Accepted: 22 August 2017 / Published online: 7 September 2017

(C) Springer-Verlag GmbH Germany 2017

\begin{abstract}
Castilla-La Mancha (central Spain) is a region characterized by significant agricultural production aimed at highquality food products such as wine and olive oil. The quality of agricultural products depends directly on the soil quality. Soil geochemistry, including dispersion maps and the recognition of baselines and anomalies of various origins, is the most important tool to assess soil quality. With this objective, 200 soil samples were taken from agricultural areas distributed among the different geological domains present in the region. Analysis of these samples included evaluation of edaphological parameters (reactivity, electrical conductivity, organic matter content) and the geochemistry of major and trace elements by X-ray fluorescence. The dataset obtained was statistically analyzed for major elements and, in the case of trace elements, was normalized with respect to $\mathrm{Al}$ and analyzed using the relative cumulative frequency (RCF) distribution method. Furthermore, the geographic distribution of analytical data was characterized and analyzed using the kriging technique, with a
\end{abstract}

Responsible editor: Zhihong Xu

Sandra Bravo

sandra.bravomc@gmail.com

1 Escuela Técnica Superior de Ingenieros Agrónomos de Ciudad Real, Universidad de Castilla-La Mancha, 13071 Ciudad Real, Spain

2 Instituto Geología Aplicada, Universidad de Castilla-La Mancha, 13400 Almadén, Ciudad Real, Spain

3 ISYMA Research Group, Mining, Energy and Materials Engineering School, University of Oviedo, c/ Independencia 13,

33011 Oviedo, Spain

4 Departamento de Geología y Geoquímica, Facultad de Ciencias, Universidad Autónoma de Madrid, 28049 Madrid, Spain

5 Escuela de Ingeniería Minera e Industrial de Almadén, 13400 Almadén, Ciudad Real, Spain correspondence found between major and trace elements in the different geologic domains of the region as well as with the most important mining areas. The results show an influence of the clay fraction present in the soil, which acts as a repository for trace elements. On the basis of the results, of the possible elements related with clay that could be used for normalization, $\mathrm{Al}$ was selected as the most suitable, followed by Fe, Mn, and Ti. Reference values estimated using this methodology were lower than those estimated in previous studies.

Keywords Geochemistry · Agricultural soils · Pedogeochemical maps $\cdot$ Physico-chemical properties

\section{Introduction}

Soil is a natural resource with a high intrinsic value for ecosystems and humans, so it must be conserved and protected, as outlined by the Commission of European Communities (Eurlex 2006). The content and distribution of chemical elements in soils depend on the composition of the parent rock, the soilforming process, climate, topography, and land use. For this reason, the chemical elements present in a soil can be lithogenic, pedogenic, and anthropogenic.

Characterization of elemental concentrations in the soils is performed by soil analysis. Such analyses show the local distribution of elements. This distribution is characterized both by the natural geochemistry, which is conditioned by the local geology, including the eventual presence of mineralization, and by the anthropogenic activities carried out in the area, which potentially lead to the dissemination of elements. Mining is the most important contaminating anthropogenic activity and it produces dispersion in the area of more minerals, which contain high concentrations of elements that are 
not generally common in rocks, e.g., "heavy metals" $(\mathrm{Pb}, \mathrm{Zn}$, $\mathrm{Cu}$, etc.), some of which are "potentially toxic/harmful elements." The distribution of chemical elements in an area includes "baseline levels," which are the concentration ranges expected in areas in which mineralization and pollution from anthropogenic activities have not occurred, and "anomalous levels," which are values outside the range of the baseline concentrations and usually produced either by the occurrence of mineralization ("geochemical anomalies") or by human activities ("contamination" or "pollution"). Reference levels represent the thresholds between baseline and anomalies, and these concepts need to be defined locally since these are different in diverse areas.

On a large scale, there are some national element dispersion maps, such as those covering Spain (IGME 2012), USA (Shacklette and Boerngen 1984), India (Chandrasekaran and Ravisankar 2015), Serbia (Mihailovic et al. 2015), England and Wales (Rawlins et al. 2012), Lithuania (Marcinkonis et al. 2011), Ireland (Fay et al. 2007), and northern Europe (Reimann et al. 2003). However, the large scales of the national maps are not appropriate for regional areas, where the unique nature of the parent materials may produce natural enrichments or the absence of elements that are not taken into account on a general scale. For this reason, in several countries, maps are now being created at the regional or local scale, including in Serbia (Mrvi et al. 2011), Barcelona Province (Bech et al. 2008, 2011), and central Catalonia (Tume et al. 2011). In Castilla-La Mancha, Jimenez-Ballesta et al. (2010) established pedogeochemical reference levels in trace elements for soils, but did not create concentration maps.

Dispersion maps supply valuable information with the aim of identifying the regional baselines and natural or anthropogenic geochemical anomalies, which in turn provides a deeper knowledge of the soils in the region. This information is an important tool for the control and planning of soil use, in particular for agricultural practices. For this reason, the main aim of the work described here was to establish a graphic framework of the soils in Castilla-La Mancha from the geochemical point of view. This framework also includes the quantification of geochemical baselines and reference levels, as well as the geographic delimitation of major geochemical areas. The final goal was to obtain an approach to identify the possible sources of the chemical elements and elucidate the reasons for the presence of anomalous levels.

\section{Study area}

Castilla-La Mancha is located at the center of the Iberian Peninsula, between the latitudes $38^{\circ} 046211-40^{\circ} 27719 \mathrm{~N}$ and the longitudes $1^{\circ} 1395-5^{\circ} 39009 \mathrm{~W}$, and it covers a surface area of $79,463 \mathrm{~km}^{2}$ (Fig. 1).

From a geological point of view, the Castilla-La Mancha territory is a relatively complex area and it includes most of the important geological domains of Spain (Gibbons and Moreno 2002; Vera 2004): a Variscan (Hercynian) basement, including metasedimentary, volcanic, and granitic/gneissic domains (Dallmeyer and Martínez-Garcia 1990), and Alpine and post-Alpine domains (Fig. 1), the latter hosting a PlioQuaternary volcanic field located in the southwest sector of the region, which overprints the Variscan and Alpine domains. The metasedimentary Variscan domain is composed of (meta)greywackes, quartzites, metapelitic sequences, and basaltic rocks of pre-Ordovician and Paleozoic age. The preOrdovician sequence crops out through central Spain and includes the so-called Complejo esquisto graváquico, a monotonous succession of slates and greywackes, whereas the Paleozoic stratigraphic sequence includes mainly slates and quartzites, with minor and localized volcano-sedimentary intercalations, such as those present in the stratigraphic column of the Almadén syncline (García Sansegundo et al. 1987; Vilas et al. 1990). The latter hosts the world's largest mercury ore deposits. The granitic and gneissic rocks are regarded here as a single unit due to their striking similarities in geochemical composition. In this respect, an important number of $\mathrm{Pb}-\mathrm{Zn}$ Ag mineral deposits from the so-called Alcudia Valley Mineral Field were formed by granite emplacement and deformation during the Variscan orogeny (e.g., Palero et al. 2003).

The Alpine domain present in the region crops out along three mountain ranges: Altomira, Iberian, and Betic, which are composed of Triassic, Jurassic, and Cretaceous sedimentary rocks, with (dolo) limestones being the dominant lithology. Of interest for this work is the presence of interbeddings of evaporitic rocks (gypsum and related rocks) of the Paleogene Age at the so-called Depresión Intermedia (Torres and Zapata 1986), as indicated in Fig. 1.

The post-Alpine domain includes a number of postorogenic sedimentary basins, with ages comprised between Miocene and Plio-Quaternary, including mostly detrital sequences, with scattered outcrops of evaporitic rocks, including sepiolite-palygorskite clay sequences (Calvo et al. 1989; Fesharaki et al. 2007); some of these sequences are topped by limestones. Part of this post-Alpine domain includes the Campos de Calatrava volcanic field (CDCVF) (Bailey et al. 2005), which is located in the Ciudad Real Province and is composed mainly of mafic rocks that are massive (lava flows) and fragmental (pyroclastic).

The existence of abandoned mineral exploitations (such as those of the Alcudia Valley and Almadén), and therefore of mining residues, has locally or regionally modified the geochemistry of soils (e.g., Higueras et al. 2003; MartínezCoronado et al. 2011). In this regard, Castilla-La Mancha is a region with an important mining history, which includes industrial rocks and minerals and metallic ores (Fig. 2). The exploitation of industrial minerals and rocks usually results in very minor modification of the local geochemistry; however, even these physical disturbances may result in local 


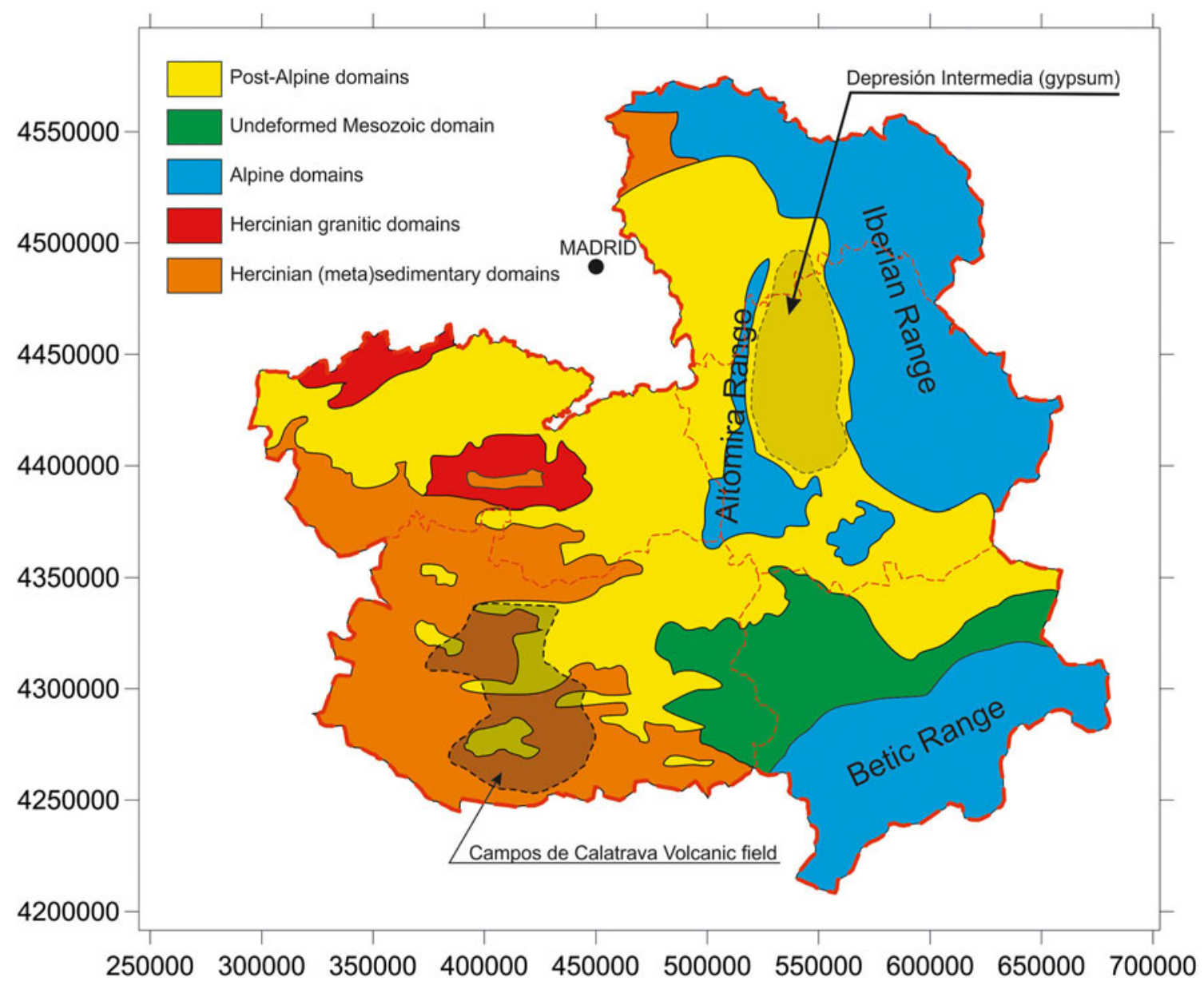

Fig. 1 Geological sketch map of the Castilla-La Mancha region based on different sources

geochemical imbalances due to the removal of soils and vegetation to exploit the rocks (e.g., granites, limestones) or sediments (e.g., clays, sands, and gravels). The Castilla-La Mancha region has been subjected to mining of fluvial sedimentary aggregates along the main river courses, such as the Tajo (Tagus) River. Furthermore, there are numerous quarries for the extraction of limestone-dolostone carbonate rocks in both Mesozoic and Cenozoic sequences. These rocks are used for different purposes, but mostly to feed aggregate and concrete (cement) industrial plants. Aggregate needs are also covered by quarrying volcanic porphyritic rocks, such as the CDCVF basalts. Other mined sequences include those of the Cenozoic Age located to the east of Molina de Aragón (Guadalajara), which are constituted by magnesites and evaporitic sequences including gypsum. These formations are particularly common in the so-called Depresión Intermedia but are also present in the Cenozoic basins.

Salts (including complex sulfates and chlorides, such as thenardite and glauberite) are also exploited in the Almansa (Albacete Province) area and to the north of Ocaña (Toledo Province). Other mined rocks and sediments include kaolin clay that accompanies the coarse Arenas de Utrillas (Utrillas Sands) of the Cretaceous Age, for example in the Iberian
Range (Guadalajara), including the Peñalén deposits, where an important clay industry developed along the high course of the Tajo River. Other deposits of kaolin include those of La Sagra, north of Toledo, although these are of the Cenozoic Age. Dimension rock quarrying includes granite and marble in the Montes de Toledo area (south of this province).

Mining of metallic ores continued until a few years ago in the Almadén mercury mining district, where the world's most important mercury deposits had been exploited since Roman times until 2003 (Hernández et al. 1999; Higueras et al. 2013; Palero et al. 2015). This mining activity resulted in districtwide contamination by mercury and this is reflected in the contents of this element in the soils, which range from high to extremely high as compared with the world's baseline concentrations (e.g., Higueras et al. 2003; Higueras et al. 2006; Martínez-Coronado et al. 2011; Garcia-Ordiales et al. 2014). Other metallic mining activities include that of the $\mathrm{Pb}-\mathrm{Zn}-\mathrm{Ag}$ deposits from the Alcudia Valley-San Quintín, all of which were small operations that nevertheless have induced locally important geochemical anomalies for these elements. A major problem relates to very high contents of $\mathrm{Pb}$ and $\mathrm{Zn}$ in the mining residues that were left after mining ceased. Some of these deposits, such as those of the San Quintín Mining 


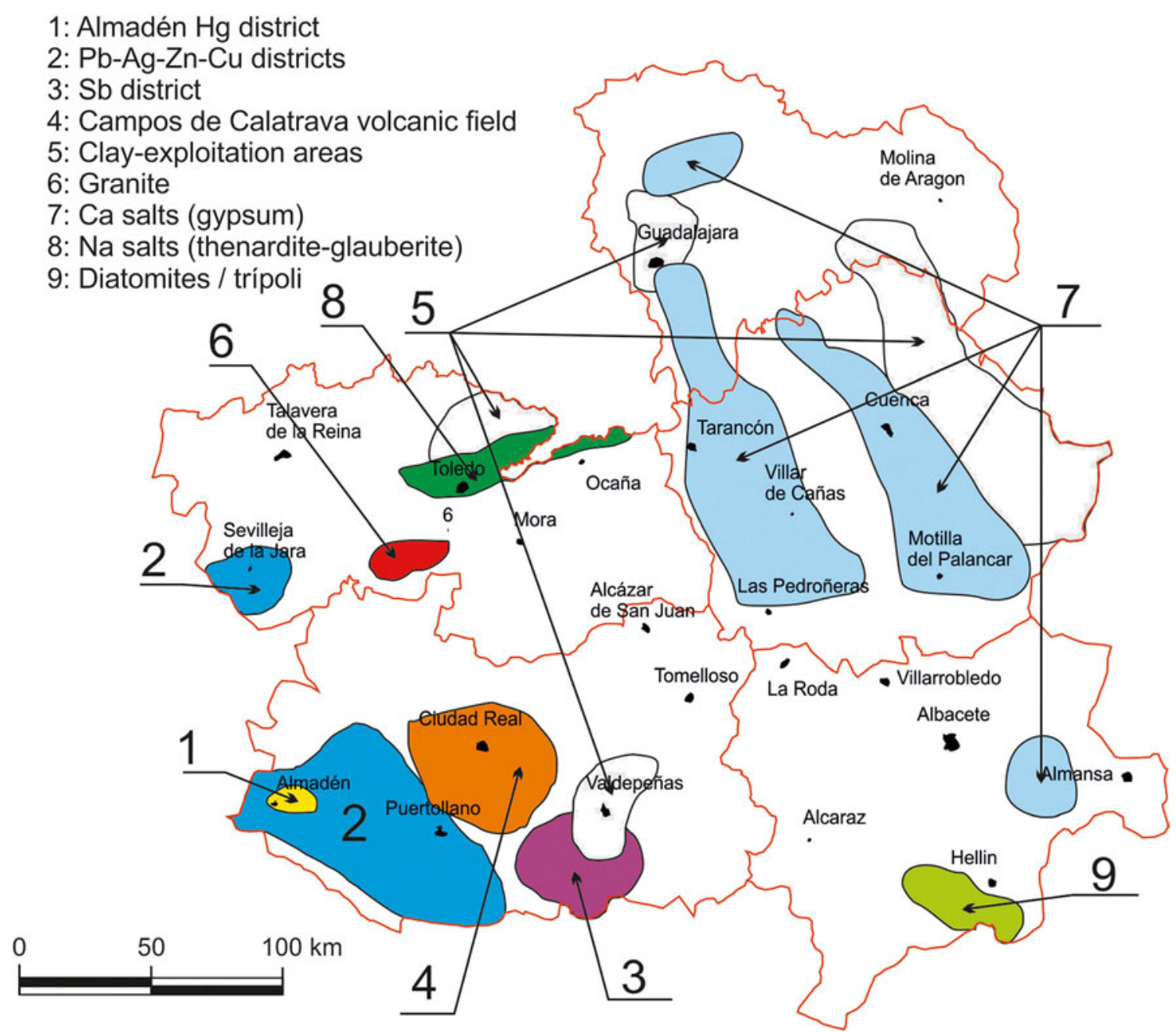

Fig. 2 Distribution of the most important mining activities carried out in the Castilla-La Mancha region. All the exploitations of metallic ores are decommissioned. Based on different sources

Group, were exploited until the mid-twentieth century and are presently surrounded by agricultural land (Rodríguez et al. 2009; Martín-Crespo et al. 2015). Other deposits of this type include those of the Sevilleja de la Jara area (SW province of Toledo) and a couple of isolated mines located to the south of Toledo and west of Alcázar de San Juan. There is also an antimony district located south of Valdepeñas (Ciudad Real) and this was exploited until the 1950s. The CDCVF also sustained the exploitation of Fe-Mn-Co-(Ni) oxide ore deposits of different morphologies that were exploited during the Second World War (Crespo et al. 1995). Several minor exploitations of iron oxides also took place to the east of Molina de Aragón (Cuenca) (Fig. 2).

The mineralogical composition of soils in the region has been studied by different authors, including Espejo (1978); García-González and Aragoneses (1991); Jimenez Ballesta et al. (1990); Vicente et al. (1991); González (2006), and Conde et al. (2009). Most of these authors describe the presence of quartz, feldspar, and clay minerals, including illite, smectite, chlorite, and kaolinite, which are characteristic of semiarid climates with a low degree of soil evolution. Most of these data refer to the Hercynian part of the region; soils from the Alpine and post-Alpine dominions are rich in carbonates (calcite) and, occasionally, in gypsum.

Amorós et al. (2015) described in detail the pedological characteristics of 110 soil profiles corresponding to vine areas from the region. In such areas, and considering the classification proposed by the Soil Survey Staff (2006), these authors recognized the presence of soils corresponding to four ordines: entisols, inceptisols, ultisols, and alfisols. In a similar way to the clay mineralogy, these data are consistent with the interpretations of regional soils as characteristic of this area, which is dominated by a semiarid climate.

The physiography of Castilla-La Mancha is complex and it includes four main characteristic landscapes: mountain (east), Hercynian basement (west and southwest), clay-rich Meseta (north), and limestone-rich Meseta (south) (Pillet 2007). The regional climate is characterized by harsh winters, hot and dry 
summers, irregular distribution of rainfall (ranging between $400 \mathrm{~mm}$ in the center to over $1000 \mathrm{~mm}$ in the mountain areas), and strong daily thermal oscillations, and thus a generalized aridity. According to the Köppen classification, the predominant climate is hot-summer Mediterranean climate (Csa) with minor areas corresponding to cold semiarid climate (Bsk), and with cool-summer Mediterranean climate (Csb) and oceanic climate $(\mathrm{Cfb})$ in the NE area (Pillet 2007).

\section{Materials and methods}

\section{Sampling works and analysis}

A soil sampling network was set up to cover all of the territories in the region and this system included 200 agricultural soils (Fig. 3). Samples were taken from trenches constructed with a backhoe and plant debris and $>2 \mathrm{~cm}$ fractions were removed in situ. The soils were described according to the criteria defined by FAO-ISRIC-IUSS (2006). Samples of top soils were collected in a carrier bag and taken to the laboratory. In the laboratory, samples were air-dried for 1 week, sieved through a $2 \mathrm{~mm}$ mesh, and split prior to the different analyses.

The soil reactivity $(\mathrm{pH})$ and electric conductivity (EC) of the samples were determined using a glass electrode in 1:2.5 $(\mathrm{V} / \mathrm{V})$ and 1:5 $(\mathrm{V} / \mathrm{V})$ suspensions of soil in deionized water, respectively, according to the methods described by Porta et al. (1986) and Richards (1954). The texture of the samples was estimated using a Bouyoucos densimeter (Gee and Bauder 1986), and the calcium carbonate content was determined using a Bernard calcimeter, according to the recommendations of Porta et al. (1986).

Prior to analysis, samples were ground in an agate mortar to obtain fine dust from which pearls were formed using lithium borate as an agglomerating additive. The pearls of soil samples were analyzed by X-ray fluorescence using a Philips PW 2404 spectrophotometer with a maximum power of $4 \mathrm{~kW}$ (set of crystal

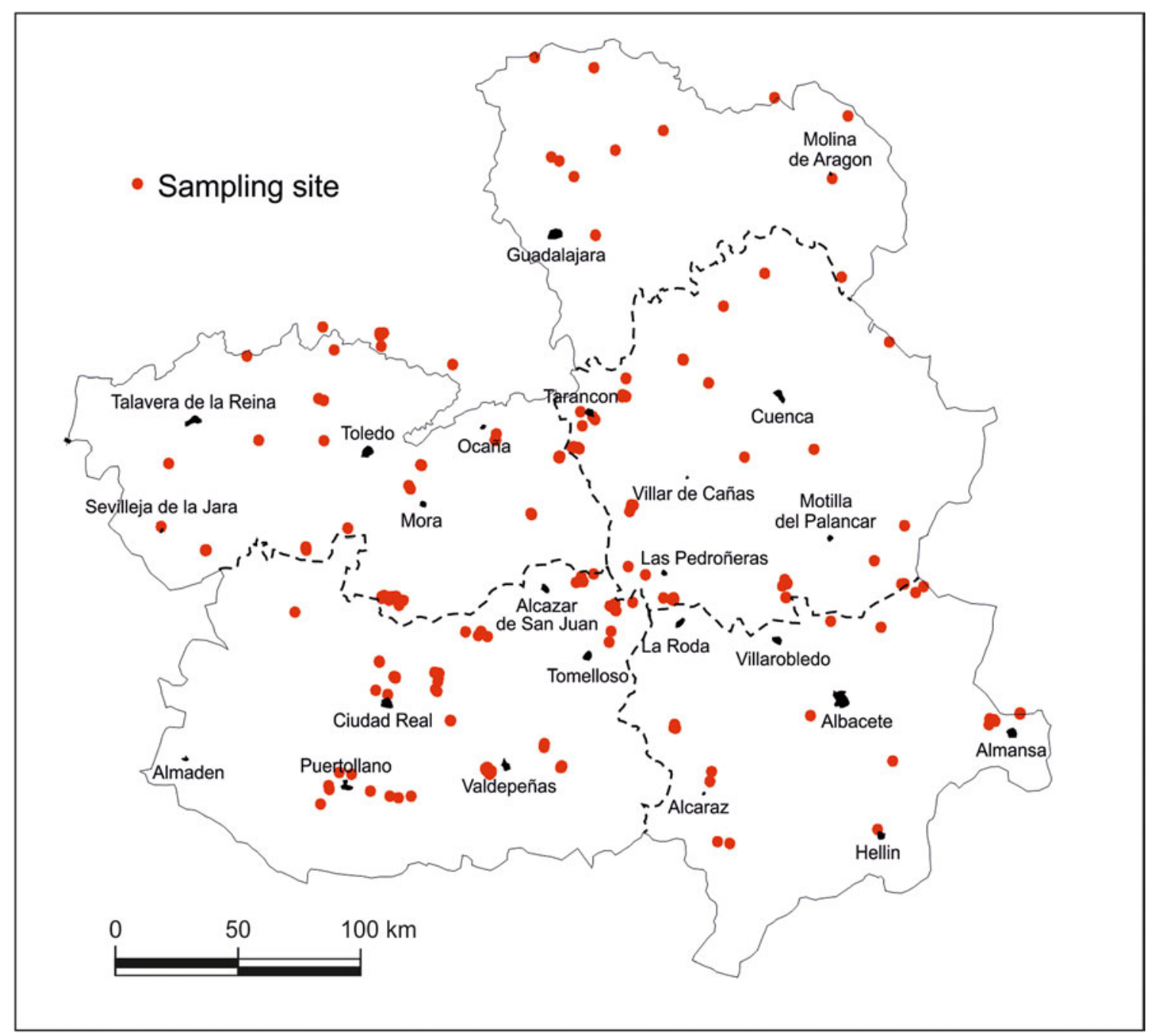

Fig. 3 Spatial distribution of the sampling sites 
analyzers for LiF220, LiF200, Ge, PET and PX1, flow detector, and twinkle detector). Samples were analyzed in batches and quality control was evaluated by duplicate analysis of certified soil reference materials (NIST 2710 and CRM 039).

\section{Data processing and rendering}

Statistical analysis, including exploratory data analysis (EDA) and relative cumulative frequency (RCF) distribution, was performed using the SPSS 19.0 and Minitab V.15 for Windows software. The RCF curves technique was applied in order to validate the results of the normalization procedure, according to the method described by Matschullat et al. (1999). As a summary of this method, in the first step, the distribution histogram of elemental concentrations is plotted to identify and to remove the outliers; in the second step, the RCF curves of each standardized elemental concentration are plotted to identify the bend cutting the dataset into the natural or geogenic baseline concentration set and anthropogenically effected concentration set. This last set was removed and the mean value of the remaining dataset was regarded as the critical value of the baseline, as proposed by Matschullat et al. (1999).

Dispersion maps were produced using Surfer 9.8.669 software (@Golden Software Inc. 2009) with the kriging option, and values were mapped considering the thresholds specified below for each element.

\section{Results and discussion}

\section{General descriptions of the studied agricultural soils}

The studied soils presented a wide range of $\mathrm{pH}$ values, varying from acid reactivity $(\mathrm{pH}=4.2)$ to strong alkaline reactivity $(\mathrm{pH}=8.9)$; however, the most common values corresponded to soils with slight alkaline reactivity $(\mathrm{pH}=7.7)$. EC measurements mostly gave low values $\left(\mathrm{EC}=0.21 \pm 0.4 \mathrm{dS} \mathrm{m}^{-1}\right)$, which indicate generalized low salt contents; however, a number of samples gave EC levels that were much higher than normal and these were soils from areas characterized by the presence of gypsum and/or other salts in the local/regional stratigraphic successions. The mean calcium carbonate content was $15.4 \%$ but the extreme values reached $67.7 \%$, which corresponds to soils with alkaline reactivity. The soil textures show an average clay content of $18.1 \%$, with values in the range 0.60 to $48.90 \%$. All these parameters are summarized in Table 1.
Table 1 Statistical summary of soil properties

\begin{tabular}{lllllllll}
\hline & Number & Mean & SD & Skewness & Kurtosis & Min & Max \\
\hline $\mathrm{pH}$ & 200 & 7.7 & 1.0 & -1.4 & 0.7 & 4.20 & 8.90 \\
$\mathrm{EC}(\mathrm{dS} / \mathrm{m})$ & 200 & 0.21 & 0.4 & 4.3 & 19.4 & 0.01 & 2.47 \\
$\mathrm{CaCO}_{3}(\%)$ & 200 & 15.4 & 16.3 & 1.0 & 0.1 & 0.10 & 67.70 \\
Clay $(\%)$ & 200 & 18.1 & 9.3 & 0.8 & 0.3 & 0.60 & 48.90 \\
\hline
\end{tabular}

\section{Elemental concentrations}

A statistical summary of the elemental concentrations and their comparison with the values reported for European and Spanish soils (according to Salminen et al. (2005) and IGME (2012), respectively) is shown in Table 2.

The median concentrations for $\mathrm{Al}, \mathrm{Fe}, \mathrm{Mn}, \mathrm{V}$, and $\mathrm{Y}$ are lower than the median values reported for European soils and similar to those for Spanish soils. For $\mathrm{As}, \mathrm{Cu}, \mathrm{Ni}$, and $\mathrm{Pb}$, the opposite trend is observed, since the median values for these elements are similar to those reported for European soils but lower than those for Spanish soils. In the case of $\mathrm{Nb}$, the median value is similar to that reported for European soils, but much higher than that for Spanish soils. This case has been studied by IGME (2012) and they interpreted the findings as being due to the presence of granite rocks, mafic volcanic rocks, and clayey rocks, which would be responsible for the anomaly in the region in question since they usually contain significant concentrations of this element. In the case of $\mathrm{Si}$, the concentrations are lower than those in European soils but comparisons with Spanish soils cannot be made as results have not been reported. The median concentrations of $\mathrm{Ba}, \mathrm{Cr}, \mathrm{Ga}$, $\mathrm{Rb}$, and $\mathrm{Zn}$ are lower than those reported for European and Spanish soils, most probably due to the significant presence of carbonate materials, which are generally deficient in these elements. The median for $\mathrm{Zr}$ is lower than that reported for Europe but it is much higher than the Spanish value. This latter finding is possibly due to the presence of tertiary clastic sediments that are rich in detrital heavy minerals in the Alpine and post-Alpine domains. In the case of $\mathrm{Th}$, the median concentration is similar to that in the European soils but lower than that in the Spanish soils - a finding that is due to the elevated levels in the crystalline basement of the Iberian Massif. Finally, Ca displays a median with concentrations well above those for Spain and Europe; however, these higher concentrations are only distributed in the eastern part of the region, which is characterized by the presence of Alpine domains that contain carbonate-rich stratigraphic successions; in the western part, which is characterized by the presence of the Hercynian (rich in silicate rocks), the Ca concentrations are generally well below this median value (see Fig. 4b). 
Table 2 Main statistics for the major elements (expressed as percentages) and trace elements (expressed as $\mathrm{mg}^{\mathrm{kg}} \mathrm{kg}^{-1}$ ) analyzed in this study

\begin{tabular}{|c|c|c|c|c|c|c|c|}
\hline & Mean & Median & SD & Minimum & Maximum & $\begin{array}{l}\text { Median European } \\
\text { soils }^{\mathrm{a}}\end{array}$ & $\begin{array}{l}\text { Median Spanish } \\
\text { soils }^{\mathrm{b}}\end{array}$ \\
\hline $\mathrm{Al}(\%)$ & 5.85 & 5.73 & 2.49 & 0.63 & 11.99 & 11.00 & 6.00 \\
\hline $\mathrm{Ca}(\%)$ & 10.49 & 6.62 & 11.78 & 0.09 & 57.59 & 1.00 & 0.80 \\
\hline $\mathrm{Fe}(\%)$ & 2.41 & 2.07 & 1.33 & 0.13 & 8.58 & 3.60 & 2.70 \\
\hline $\operatorname{Mn}(\%)$ & 0.06 & 0.04 & 0.08 & 0.002 & 0.54 & 0.06 & 0.04 \\
\hline $\mathrm{Si}(\%)$ & 25.06 & 25.37 & 9.79 & 0.05 & 46.33 & 31.79 & - \\
\hline $\mathrm{Ti}(\%)$ & 0.41 & 0.30 & 0.74 & 0.03 & 9.38 & 0.34 & 0.23 \\
\hline As & 8.31 & 7.55 & 6.02 & 0.03 & 41.20 & 6.50 & 14.00 \\
\hline $\mathrm{Ba}$ & 214.23 & 194.20 & 99.94 & 47.50 & 697.90 & 380.00 & 338.00 \\
\hline $\mathrm{Cr}$ & 42.68 & 35.80 & 20.91 & 15.00 & 115.50 & 61.00 & 57.00 \\
\hline $\mathrm{Cu}$ & 17.38 & 14.10 & 12.22 & 2.90 & 70.40 & 13.50 & 17.50 \\
\hline $\mathrm{Ga}$ & 10.27 & 9.30 & 5.65 & 0.90 & 35.90 & 13.50 & 17.00 \\
\hline $\mathrm{Nb}$ & 11.57 & 10.80 & 4.04 & 0.90 & 22.40 & 9.70 & 0.70 \\
\hline $\mathrm{Ni}$ & 25.43 & 19.25 & 19.20 & 1.30 & 122.30 & 19.50 & 25.50 \\
\hline $\mathrm{Pb}$ & 25.77 & 19.20 & 24.14 & 1.00 & 249.50 & 19.40 & 26.50 \\
\hline $\mathrm{Rb}$ & 81.16 & 66.65 & 56.74 & 10.90 & 377.30 & 81.50 & 103.00 \\
\hline Th & 10.15 & 9.10 & 6.28 & 0.30 & 51.10 & 7.50 & 14.00 \\
\hline $\mathrm{V}$ & 59.35 & 51.00 & 35.25 & 6.00 & 187.30 & 61.00 & 49.00 \\
\hline $\mathrm{Y}$ & 19.68 & 17.70 & 9.29 & 5.40 & 51.40 & 22.00 & 18.00 \\
\hline $\mathrm{Zn}$ & 43.48 & 37.65 & 28.28 & 5.00 & 225.00 & 50.00 & 57.00 \\
\hline $\mathrm{Zr}$ & 252.78 & 199.35 & 168.19 & 12.40 & 947.80 & 225.00 & 63.00 \\
\hline
\end{tabular}

$S D$ standard deviation

${ }^{a}$ Data from Salminen et al. (2005)

${ }^{\mathrm{b}}$ Data from IGME (2012)

\section{Regional distribution characteristics of major elements}

The dispersion of Al (Fig. 4) shows higher concentrations of this element in the soils of the western zone of the region, which coincides with the area of the Hercynian domain (Fig. 1) where the presence of sedimentary, metamorphic, and plutonic rocks affected by Hercynian orogeny provides an Al-rich substrate from minerals such as feldspars and phyllosilicates (micas and clays).

In the case of calcium (Fig. 4), the highest concentrations are located in the western zone of the region and these coincide with the Alpine domain (Fig. 1), which is present along three mountain ranges: Altomira, Ibérica, and Betica. The geology of these areas mainly consists of sedimentary Triassic, Jurassic, and Cretaceous rocks, including carbonate rocks such as limestones and dolomites and other Ca-rich minerals (gypsum), which are the main sources of the most significant contributions of this element in these areas.

The highest concentrations of Fe (Fig. 4) are located in the north and south of the region and most of these are in areas of Hercynian dominion and part of the Alpine domain of the Betic Zone in the southern area (Fig. 1). In the southern area, the zone with the highest Fe content coincides with the area of the Alcudia Valley, where the presence of minerals rich in pyrite is responsible for these higher contents. In the northern area, the high contents are located in the Hayedo de Tejera Negra Zone, where petrologic-stratigraphic groups predominate with metamorphic Palaeozoic materials (slate, schist, and quartzite) together with the dispersed presence of plutonic and volcanic rocks (Capote 1981).

The dispersion of Mn concentrations (Fig. 4) throughout the territory shows that the maximum values are related to materials of the Hercynian domain and, more specifically, the maximum values correspond to the area of the Calatrava volcanic field, which contains mineralizations rich in this element and associated with the mafic volcanism characteristic of this region. On the other hand, the lowest concentrations correspond to the domains of post-Alpine, Mesozoic, and Alpine sedimentary materials due to the low levels of this element in the carbonated lithotypes.

\section{Regional distribution characteristics of trace elements}

\section{Geochemical baselines}

The baseline concentrations of trace elements in soils and sediments, which are regarded as the natural abundance of 


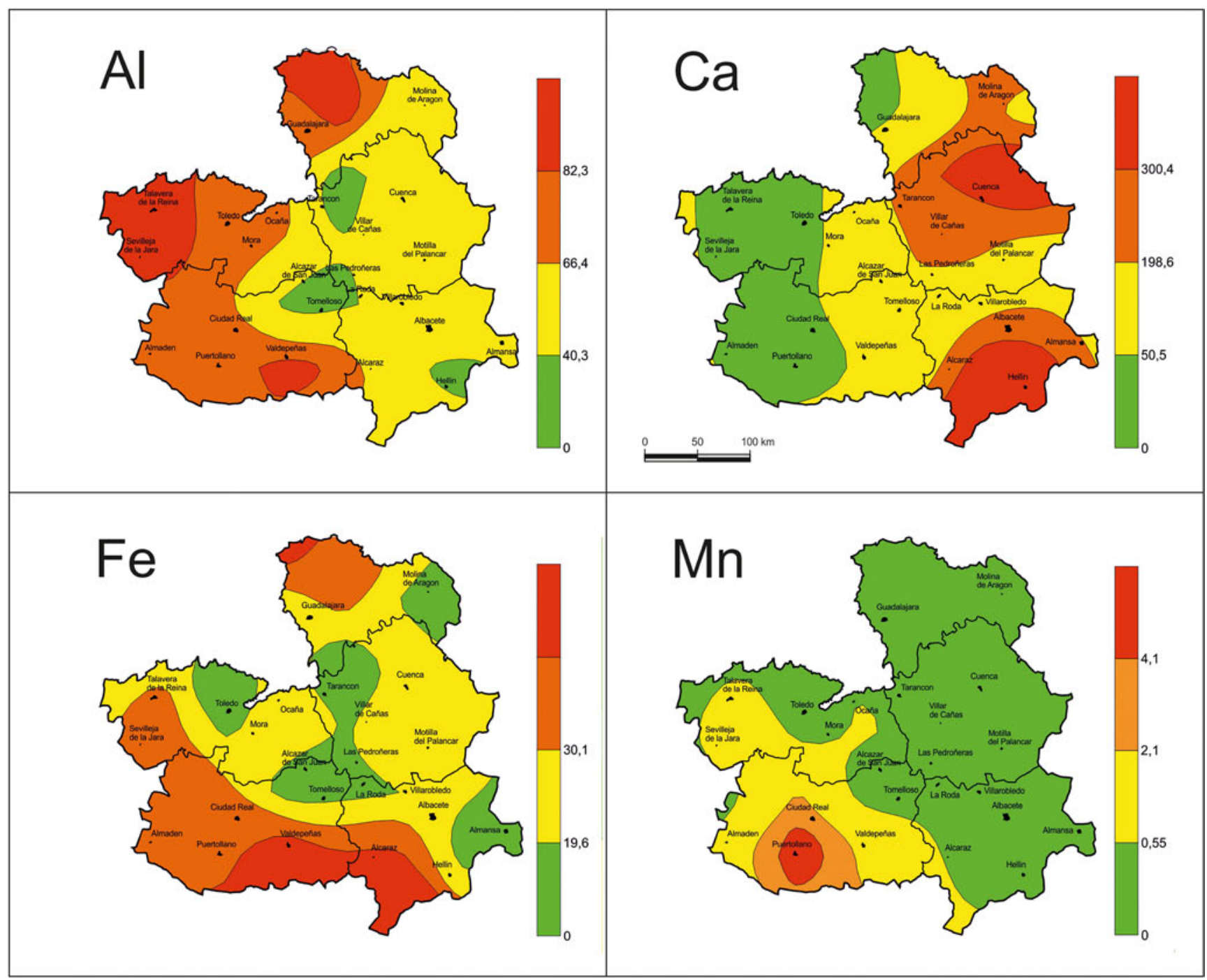

Fig. 4 Distribution of major elements in agricultural soils of the Castilla-La Mancha region, correspondig to Al, Ca, Fe and Mn. Thresholds used correspond to the 30 th, 60 th, and 90 th percentiles. All data in percentages

an element in a particular material such as soil, sediment, or rock with respect to a particular area or dataset (Zhang et al. 2007), are mainly influenced by the geochemistry and mineralogy of the substrate. Furthermore, the contents in clay and SOM also have an influence on this parameter (Diez et al. 2007; Roca et al. 2008). However, these independent variables are not sufficient to explain baseline trace element concentrations in soil and the consideration of other variables usually improves the model (Tack et al. 1997). To overcome this drawback of the "clay fraction," data normalization is often carried out considering "conservative elements" such as Al, $\mathrm{Fe}, \mathrm{Li}$, and $\mathrm{Rb}$ (Reimann et al. 2005; Zhang et al. 2009; Hu et al. 2013; Song et al. 2014).

As mentioned in "Introduction," the clay mineralogy in the soils of the region is dominated by kaolinite, illite, and montmorillonite. In general terms, weathering of the parent lithological material produces an increase in $\mathrm{Fe}, \mathrm{Ti}$, and $\mathrm{Al}$ over time, together with some trace elements, due to the formation of secondary phases upon which these elements can be fixed during weathering (Malpas et al. 2001). Thus, as the geochemical behavior of trace elements is in part controlled by the type and abundance of clay minerals, the reference element used for the determination of the geochemical baseline must be an important constituent of these minerals. Furthermore, the normalizing element must be a significant constituent of one or more of the major trace metal carriers (i.e., minerals) and must reflect their weathering state in soils (Song et al. 2014). As a consequence, $\mathrm{Fe}, \mathrm{Ti}, \mathrm{Al}$, and $\mathrm{Mn}$ could be selected to be the reference elements based on the results of clay mineralogy analysis as they are important elements that form the aforementioned mineralogical species detected in the clay fraction. Correlation analysis between the clays and the trace elements in question was performed to identify which of these elements show better behavior as a normalizing element. It can be seen from Fig. 5 that $\mathrm{Al}$ and $\mathrm{Fe}$ seem to be the best reference elements as they have significant positive relationships with 


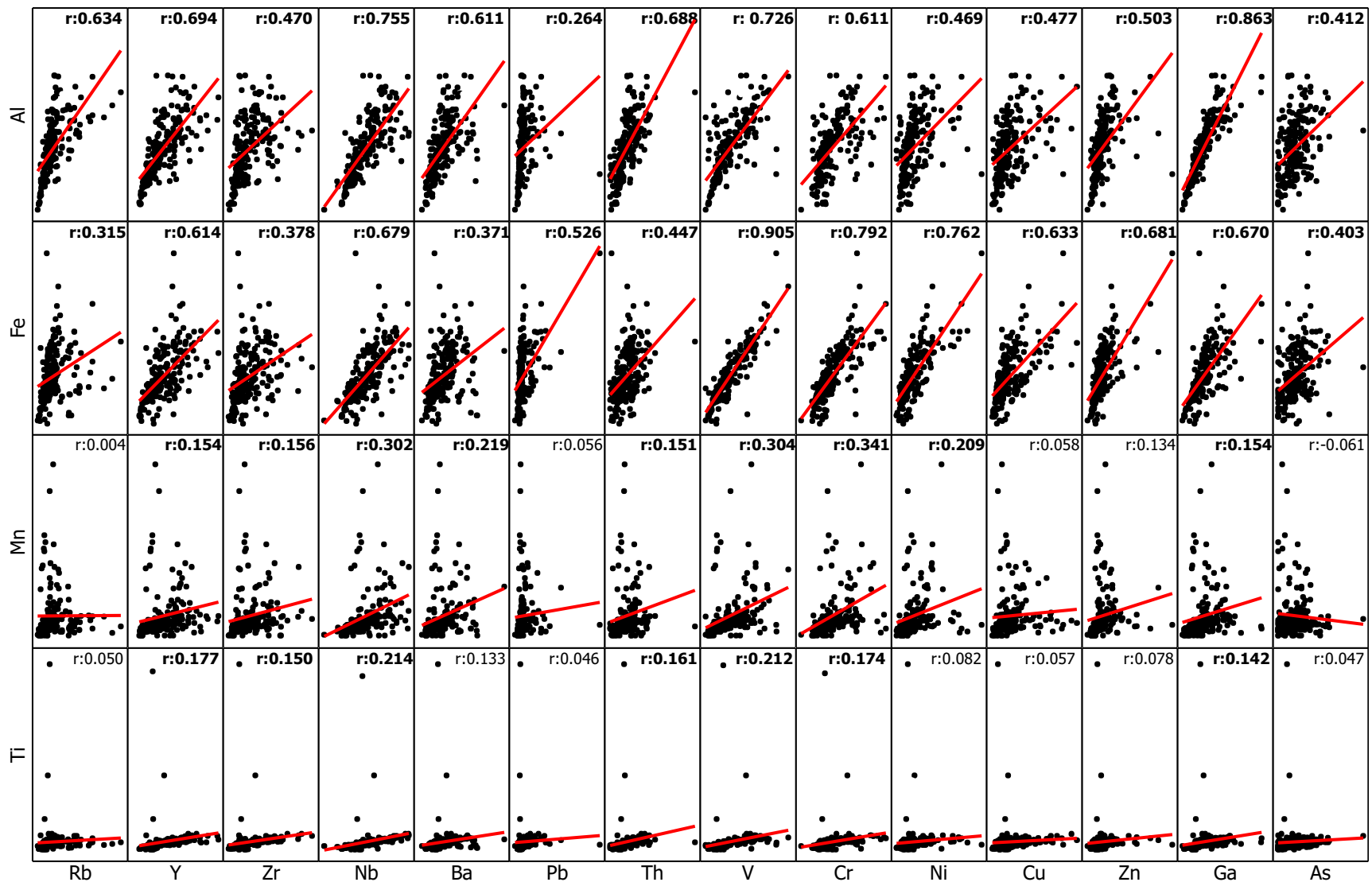

Fig. 5 Correlation matrix for trace elements with potential use as normalizing parameters. Values highlighted in bold indicate a significance $p<0.05$

all of the elements in question. Considering that Fe concentrations in agricultural soils may be influenced by anthropogenic inputs as a consequence of its use as a micronutrient in fertilizers, we finally selected $\mathrm{Al}$ as the reference element to perform this normalization.

Once the normalizing element had been selected, the geochemical baseline levels (GBLs) for each element were determined. This step was carried out using the RCF method as a function of the elemental concentration normalized with respect to Al (Covelli and Fontolan 1997; Suh and Birch 2005). The RCF curve was generated to validate the results of the normalization procedure. A statistical explorative test was used before computing the RCF in order to remove the extreme outliers, which we assumed to be a consequence of anthropogenic or extreme natural events. The RCF was then generated from the cleaned dataset as a function of the elemental concentration, normalizing with respect to the selected normalized element, which in this case was $\mathrm{Al}$ (Fig. 6).

As a general observation, the RCF of each element, normalized with respect to $\mathrm{Al}$, displays at least one turning point in the slope, which divides the dataset into two sections: the values below the slope change are considered as a geogenic baseline set, and the values above the slope change are considered as representative of the sample set affected by anthropogenic contributions or other natural but abnormal event(s). The value corresponding to the slope change is defined as the reference level and this is the upper limit of the baseline range. The mean value of the first section of the slope was regarded as the critical value of the baseline, as proposed by Matschullat et al. (1999). The RCFs for each element are shown in Fig. 6 and the GBL results are shown in Table 3, which also contains, as comparative values, reference and baseline values previously estimated for the soils of CastillaLa Mancha (Jimenez-Ballesta et al. 2010).

The predicted geochemical baselines are different from previously reported ones, although both cover the same geographical and geological areas. It is worth noting that for the previous estimation of GBL values for Castilla-La Mancha soils, 72 samples were used (Jimenez-Ballesta et al. 2010), while in our study a total of 200 samples was analyzed. This difference in the number of samples and in the data processing methodology is the cause of the variations detected. The much larger number of samples in our dataset certainly covers in greater depth the different parent lithologies present in the studied territory and allows the accuracy error in the GBL determination to be reduced. In general, our GBL values show less variability 

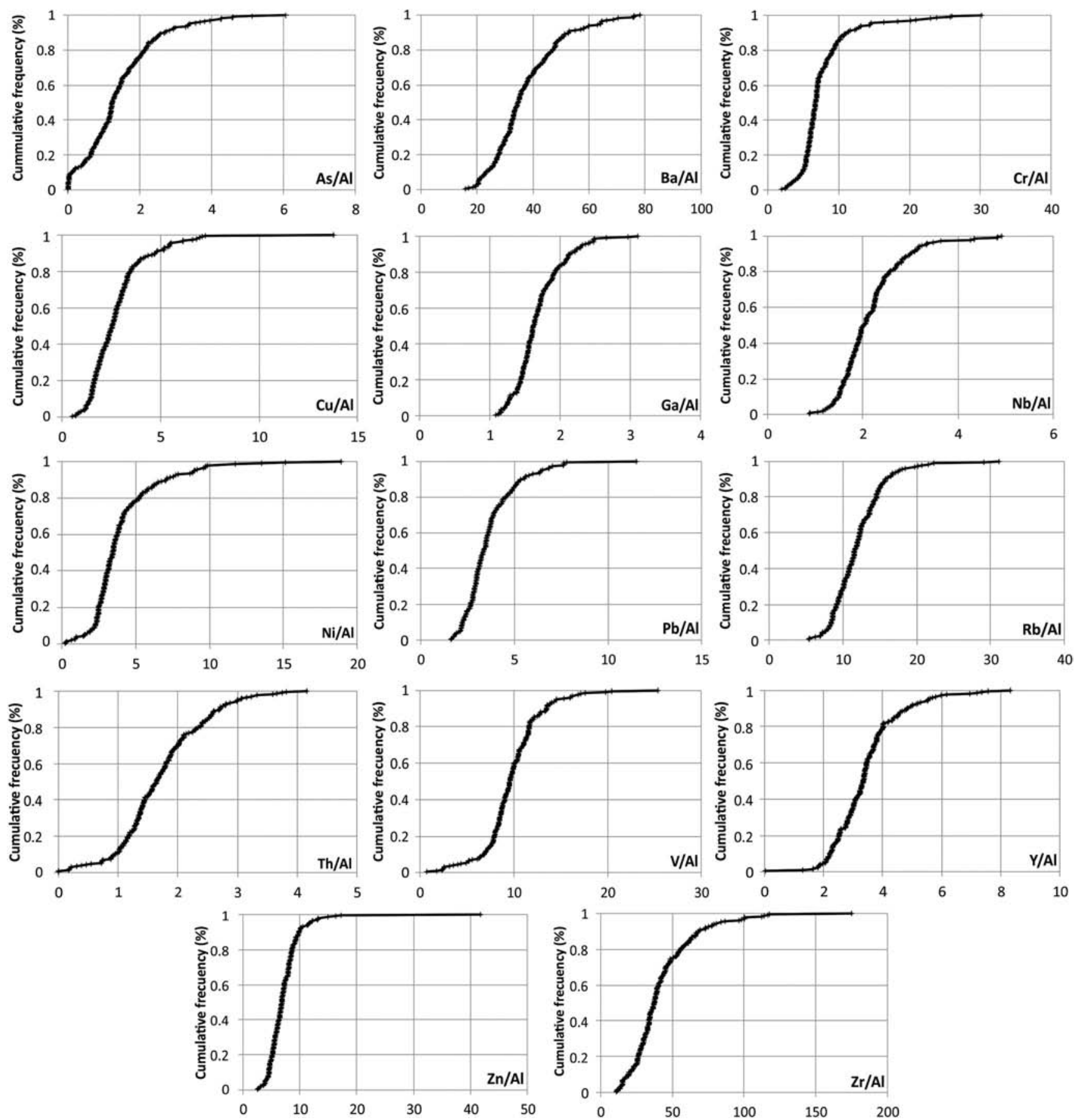

Fig. 6 Relative cumulative frequency (RCF) curves for normalized trace elements concentrations

and most of the reference values are lower than those estimated previously. While $\mathrm{As}, \mathrm{Nb}, \mathrm{Y}$, and $\mathrm{Zr}$ show similar GBL, the rest of the studied elements display GBL values that are below $30 \%$ of the previous values, thus suggesting an overestimation of the previous baseline values. We consider that this is an indication of the quality of this methodology, which involves the consideration of extremely high values as outliers that cannot be used for baseline estimation.

\section{Dispersion maps}

In order to show the general dispersion trends for trace elements and to select representative element distributions to display graphically, a cluster analysis was performed with the trace element dataset normalized with respect to $\mathrm{Al}$. Cluster analysis was performed on the basis of the values of 17 standardized variables using Ward's hierarchical agglomerative method and Euclidean distance measures. The results 
Table 3 Geochemical baselines computed by the normalization procedure and measured results

\begin{tabular}{lllll}
\hline & $\begin{array}{l}\text { Geochemical baselines for } \\
\text { Castilla-La Mancha } \\
\text { agricultural soils }\left(\mathrm{mg} \mathrm{kg}^{-1}\right)\end{array}$ & $\begin{array}{l}\text { Reference values } \\
\left(\mathrm{mg} \mathrm{kg}^{-1}\right)\end{array}$ & $\begin{array}{l}\text { Geochemical baselines } \\
\text { for Castilla-La Mancha } \\
\text { soils }\left(\mathrm{mg} \mathrm{kg}^{-1}\right)^{\mathrm{a}}\end{array}$ & $\begin{array}{l}\text { Reference values } \\
\left(\mathrm{mg} \mathrm{kg}^{-1}\right)^{\mathrm{a}}\end{array}$ \\
\hline $\mathrm{As}$ & $6.5 \pm 3.8$ & 14.1 & $7.4 \pm 4.2$ & 15.8 \\
$\mathrm{Ba}$ & $195.1 \pm 71.6$ & 338.3 & $389.9 \pm 329.6$ & 1049.1 \\
$\mathrm{Cr}$ & $39.9 \pm 14.6$ & 69.1 & $54.8 \pm 29.2$ & 113.2 \\
$\mathrm{Cu}$ & $10.9 \pm 3.7$ & 18.3 & $10.3 \pm 8.3$ & 26.9 \\
$\mathrm{Ga}$ & $8.2 \pm 3.9$ & 16.0 & $11.1 \pm 7.7$ & 26.5 \\
$\mathrm{Nb}$ & $11.4 \pm 3.4$ & 18.2 & $8 \pm 5.3$ & 18.6 \\
$\mathrm{Ni}$ & $17.3 \pm 6.9$ & 31.1 & $16.9 \pm 12.8$ & 42.5 \\
$\mathrm{~Pb}$ & $17.9 \pm 4.6$ & 27.1 & $19.3 \pm 12.3$ & 43.9 \\
$\mathrm{Rb}$ & $55.1 \pm 20.7$ & 96.5 & $86.2 \pm 74.2$ & 234.6 \\
$\mathrm{Th}$ & $7.9 \pm 3.4$ & 14.7 & $9.6 \pm 6.0$ & 123.1 \\
$\mathrm{~V}$ & $43.0 \pm 21.0$ & 85.0 & $49.9 \pm 36.6$ & 38.1 \\
$\mathrm{Y}$ & $16.8 \pm 7.6$ & 32.0 & $17.9 \pm 10.1$ & 86.5 \\
$\mathrm{Zn}$ & $35.0 \pm 11.1$ & 57.2 & $35.7 \pm 25.4$ & 413.0 \\
$\mathrm{Zr}$ & $180.5 \pm 92.3$ & 365.1 & $167.6 \pm 122.7$ & \\
\hline
\end{tabular}

${ }^{\text {a }}$ Values estimated by Jimenez-Ballesta et al. (2010)
(Fig. 7) display a nice clustering of variables into three main clusters: the first cluster includes the elements Al and Mn with $\mathrm{As}, \mathrm{Rb}$, and $\mathrm{Ga}$, and this should be a lithogenic cluster related with the clay matrix; the second cluster includes the elements $\mathrm{Y}, \mathrm{Zr}$, and $\mathrm{Th}$, with $\mathrm{Nb}$ and $\mathrm{Ba}$, separated from the first cluster but also related to the lithologic component; finally, Fe and V, with $\mathrm{Pb}, \mathrm{Zn}$, and $\mathrm{Cu}$, and with $\mathrm{Ni}$ and $\mathrm{Cr}$, constitute a third cluster that is very probably related to contamination associated with anthropogenic activities, including mining.

Based on this dendrogram, we selected the elements Rb, Y, $\mathrm{Ba}, \mathrm{V}, \mathrm{Zn}$, and $\mathrm{Ni}$ to represent the corresponding isocontent maps for the region (Fig. 8). In order to note the distribution of baseline concentrations with respect to those concentrations that could be considered as anomalous, we employed as successive mapping thresholds the geochemical baseline, the reference value (both shown in Table 3), and the 90th percentile (only to highlight the most "anomalous" areas).

The distribution of $\mathrm{Rb}$ (Fig. 8) is significantly different between the eastern and western portions of the region, with higher concentrations of the element in the west, which is dominated by Hercynian (meta)sedimentary rocks, and with maximum concentrations in the NW area, where granitic rocks are predominant, which usually contain relatively high $\mathrm{Rb}$ concentrations (Mielke 1979; IGME 2012). Ga and As show
Fig. 7 Dendrogram corresponding to the cluster analysis of normalized elements

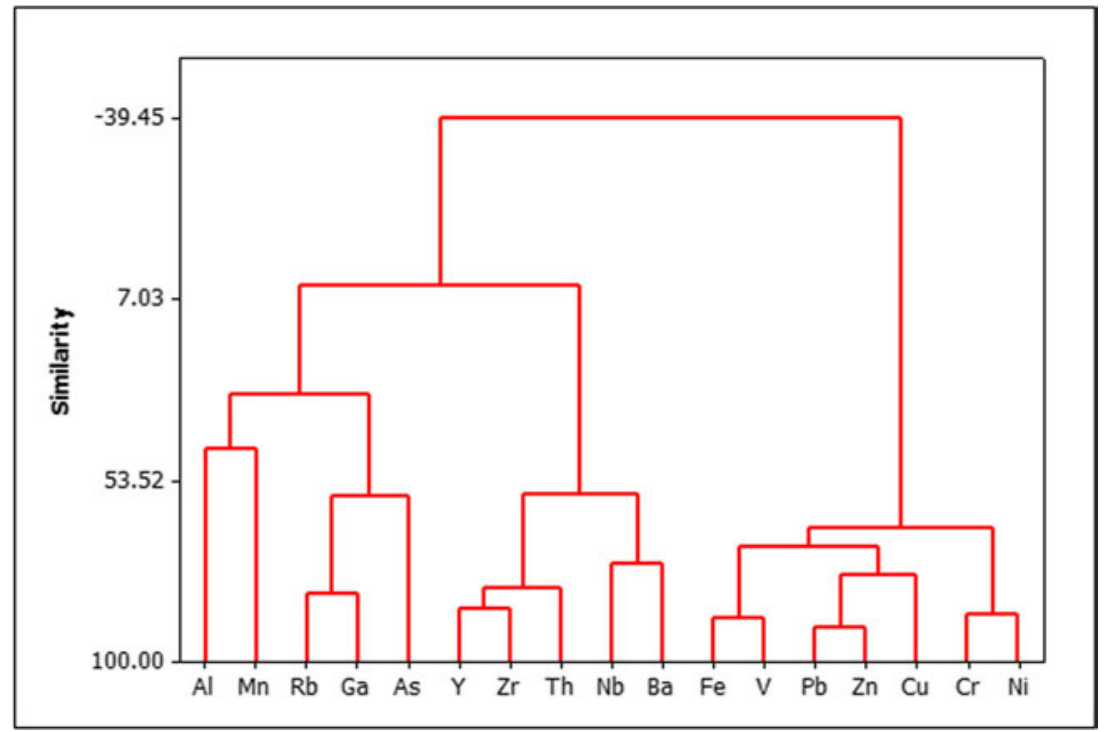




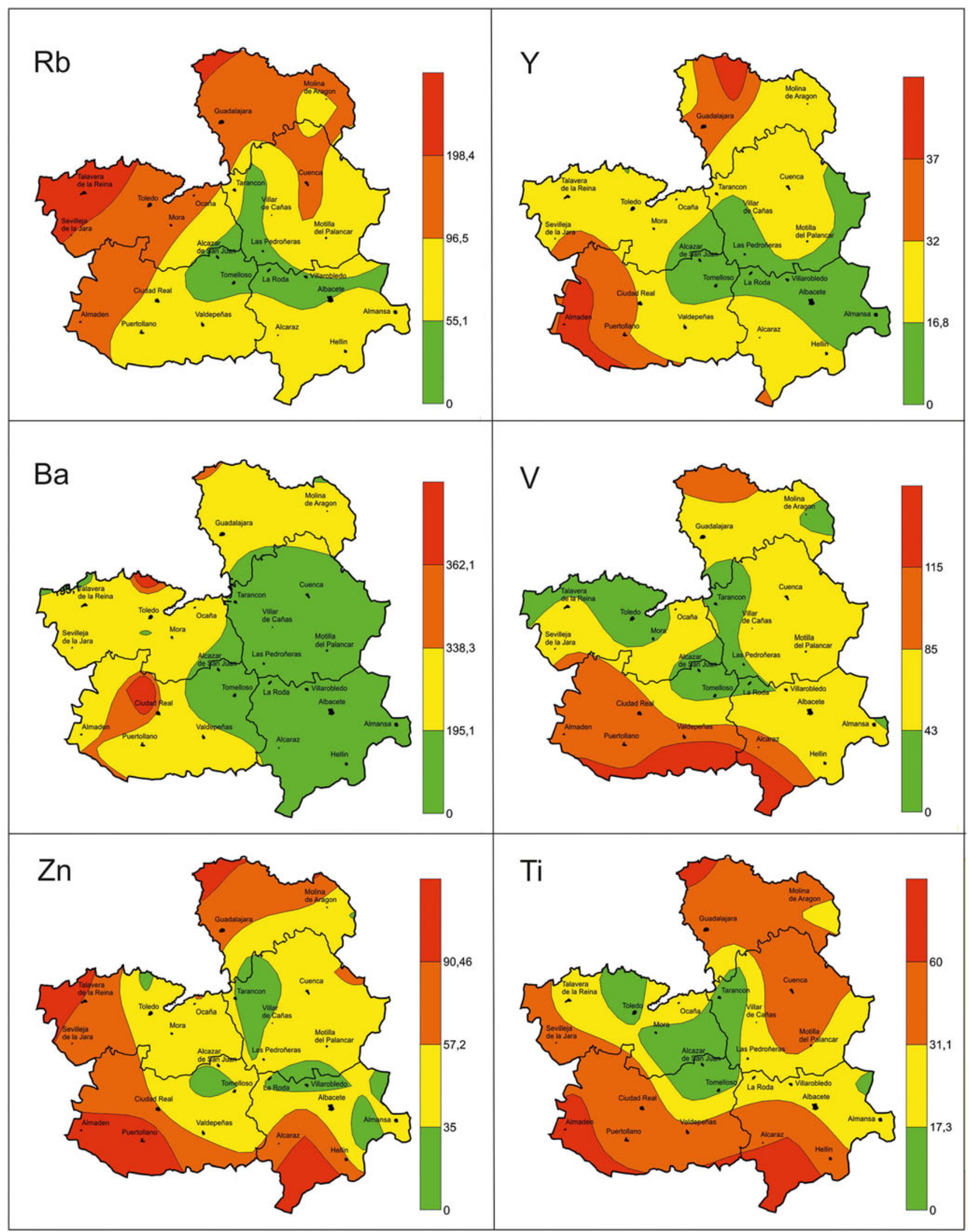

Fig. 8 Distribution of selected trace elements (Rb, Y, Ba, V, Zn and Ti) in the agricultural soils of the Castilla-La Mancha region. Thresholds used correspond to the geochemical baseline, the reference value, and the 90th percentile. All values in parts per million-milligrams per kilogram 
similar dispersion patterns to $\mathrm{Rb}$, with the maximum contents associated with the granitic areas, where these elements usually appear due to their oxidation states $\mathrm{As}^{3+}$ and $\mathrm{Ga}^{3+}$, replacing $\mathrm{Al}^{3+}$ or $\mathrm{Fe}^{3+}$ in amphibole, feldspar, and mica (Salminen et al. 2005).

The maximum concentrations of Y (Fig. 8), Zr, and Th also seem to be conditioned by the presence of (meta)sedimentary rocks in the Hercynian realm, in the northern and SW areas of the region. These anomalies correspond to those previously reported by the national geochemical maps from IGME (2012) and they seem to be related to the presence of calcareous rocks in the Albarracín Range (northern area) and with the presence of the CDCVF (SW area).

Barium (Fig. 8) and $\mathrm{Nb}$ have few concentration values above the reference value, indicating a generalized geogenic presence in the region with no particular alterations of the general baseline. The maximum values appear in areas dominated by Hercynian (meta)sedimentary rocks.

Vanadium (Fig. 8) and Fe (Fig. 4) show an approximate coincident geographical distribution with that of $\mathrm{Zn}$, with maximum values in the south (Ciudad Real-Valle de Alcudia) and north of Guadalajara Province. In the same way as $\mathrm{Zn}$ and related elements, high concentrations in the southern area can be explained by industrial and mining activities, while the values in the north are of unknown origin.

The map for $\mathrm{Zn}$ concentrations (Fig. 8), as for $\mathrm{Pb}$ and $\mathrm{Cu}$, displays a distribution partly conditioned by the presence of $\mathrm{Pb}-\mathrm{Zn}-\mathrm{Ag}$ ore deposits in the SW of the region (the Alcudia Valley-San Quintín and the Sevilleja de la Jara districts); however, maximum concentrations in the northern area (Guadalajara Province) are not explained by the presence of this type of mineralization.

The concentrations of $\mathrm{Ni}$ (Fig. 8) show a distribution as significant as that of $\mathrm{V}$, with maximum values located at the $\mathrm{S}-\mathrm{SW}$ and N-NE of the region and with minimum values in the central zone. There are no clear indications for the interpretation of this distribution as being related to natural or anthropogenic-induced values.

\section{Conclusions}

The present study shows that the distribution of major and trace elements in agricultural soils from the Castilla-La Mancha region is governed by lithologic factors. Anthropogenic influence is practically negligible for most of the elements studied.

Aluminum, as an important constituent of the clay fraction of soil, proved to be a good reference element for the normalization and improved analysis of the distribution of elements in the agricultural soils of the region. Baseline concentrations of trace elements, estimated using aluminum as a normalizing reference, appear to provide sound values that are lower than those previously estimated for the region soils. This implies that previously reported values could be overestimated as they did not take into account geochemical associations that play an important role in baseline concentrations.

The correct application of baseline values gives rise to a better assessment of risks related with the presence of anomalous concentrations in potentially toxic elements.

Funding This study was funded by the Castilla-La Mancha regional government (PPII10-0063-8230) and by the Spanish Ministry of Science and Innovation (Grant CGL2015-67644-R).

\section{References}

Amorós JA, Bravo S, García-Navarro FJ, Pérez-De-Los-Reyes C, Chancón JL, Martínez J Jiménez-Ballesta R (2015) Atlas de suelos vitícolas de Castilla La Mancha. Arte y comunicación Calatrava. Financiado por Globalcaja-UCLM, 318 pg ISBN 978-84-6081398-9

Bailey K, Garson M, Kearns S, Velasco AP (2005) Carbonate volcanism in Calatrava, central Spain: a report on the initial findings. Mineral Mag 69(6):907-915

Bech J, Tume P, Sokolovska M, Reverter F, Sanchez P, Longan L, Bech J, Puente A, Oliver T (2008) Pedogeochemical mapping of Cr, Ni, and $\mathrm{Cu}$ in soils of the Barcelona Province (Catalonia, Spain): relationships with soil physico-chemical characteristics. J Geochem Explor 96:106-116

Bech J, Reverter F, Tume P, Sanchez P, Longan L, Bech J, Oliver T (2011) Pedogeochemical mapping $\mathrm{Al}, \mathrm{Ba}, \mathrm{Pb}, \mathrm{Ti}$ and $\mathrm{V}$ in surface soils of the Barcelona Province (Catalonia, Spain): relationships with soil physicochemical characteristics. J Geochem Explor 109:26-37

Calvo JP, Zarza AMA, Del Cura MAG (1989) Models of Miocene marginal lacustrine sedimentation in response to varied depositional regimes and source areas in the Madrid Basin (central Spain). Palaeogeogr Palaeoclimatol Palaeoecol 70(1):199-214

Capote R (1981) La tectónica Hercínica de cabalgamientos en el Sistema Central Español. Cuadernos de Geología Ibérica, 7

Chandrasekaran A, Ravisankar R (2015) Spatial distribution of physicochemical properties and function of heavy metal in soil of Yelagiri hills, Tamilnadu by energy dispersive X-ray florescence spectroscopy (EDXFR) with statistical approach. Spectrochim Acta A Mol Biomol Spectrosc 150:586-601

Conde P, Martín Rubí JA, García R, Jiménez BR (2009) Determination of the neutralization capacity of soils using abrasion $\mathrm{pHs}$, base cations concentrations and mineralogy in Castilla La Mancha (Spain). Fresenius Environ Bull 18(3):280-293

Covelli S, Fontolan G (1997) Application of a normalization procedure in determining regional geochemical baselines. Environ Geol 30(1): $34-45$

Crespo A, Lunar R, Oyarzun R, Doblas M (1995) Unusual case of hot springs-related Co-rich Mn mineralization in central Spain: the Pliocene Calatrava deposits. Econ Geol 90(2):433-437

Dallmeyer RD, Martínez-Garcia E (1990) Pre-Mesozoic geology of Iberia. Springer-Verlag, Berlin 535 pg. ISBN: 978-3-642-83982-5

Diez M, Simon M, Dorronsoro C, Garcia I, Martin F (2007) Background arsenic concentrations in southeastern Spanish soils. Sci Total Environ 378(1):5-12

Espejo R (1978) Estudio del perfil edáfico y caracterización de las superficies tipo raña del sector Cañamero-Horcajo de los Montes. PhD Dissertation, ETSI Agrónomos de Madrid, UPM. 469 pp

Eur-lex (2006) Proposal for a directive of the European Parliament and of the Council establishing a framework for the protection of soil and 
amending Directive 2004/35/EC http://eur-lex.europa.eu/ LexUriServ/LexUriServ.do?uri=COM:2006:0232:FIN:en:PDF

FAO-ISRIC-IUSS (2006) World reference base for soil resources. A framework for international correlation and communication. World soil resources report. FAO, Rome

Fay D, Kramers G, Zhang C, McGrath D, Grennan E (2007) Soil geochemical atlas of Ireland. Teagasc. Environmental Research Centre. University of Ireland, Galway

Fesharaki O, García-Romero E, Cuevas-González J, López-Martínez N (2007) Clay minerals genesis and chemical evolution in the Miocene sediments of Somosaguas, Madrid Basin, Spain. Clay Miner 42(2): $187-201$

García Sansegundo J, Lorenzo Álvarez S, Ortega E (1987) Mapa Geológico Nacional a escala 1:50.000. Hoja $n^{\circ} 808$ (Almadén). IGME, Madrid

García-González MT, Aragoneses FJ (1991) Transformaciones mineralógicas en suelos sobre formaciones tipo "raña". Suelo y Planta 1:735-747

Garcia-Ordiales E, Loredo J, Esbrí JM, Lominchar MA, Millan R, Higueras P (2014) Stream bottom sediments as a means to assess metal contamination in the historic mining district of Almadén (Spain). Int J Min Reclam Environ 28(6):357-376

Gee GW, Bauder JW (1986) Particle-size analysis. In: Klute A (ed) Methods of soil analysis. Part 1. Physical and mineralogical methods, 2nd ed. Agronomy monograph no.9, ASA-SSSA, Madison, $\mathrm{p}$ 383-41

Gibbons W, Moreno T (2002) The geology of Spain. The Geological Society, London $649 \mathrm{pp}$

González V (2006) Metodología, formulación y aplicación de un índice de calidad de suelos con fines agrícolas para Castilla-la Mancha. PhD Dissertation, Universidad Autónoma de Madrid

Hernández A, Jébrak M, Higueras P, Oyarzun R, Morata D, Munhá J (1999) The Almadén mercury mining district, Spain. Mineral Deposita 34:539-548

Higueras P, Oyarzun R, Biester H, Lillo J, Lorenzo S (2003) A first insight into mercury distribution and speciation in the Almadén mining district, Spain. J Geochem Explor 80:95-104

Higueras P, Oyarzun R, Lillo J, Sánchez Hernández JC, Molina JA, Esbrí JM, Lorenzo S (2006) The Almadén district (Spain): anatomy of one of the world's largest Hg-contaminated sites. Sci Total Environ 356: $112-124$

Higueras P, Oyarzun R, Morata D (2013) Intraplate mafic magmatism, degasification, and deposition of mercury: the giant Almadén $\mathrm{Hg}$ deposit (Spain) revisited. Ore Geol Rev 51:93-102

Hu B, Cui R, Li J, Wei H, Zhao J, Bai F, Son W, Ding X (2013) Occurrence and distribution of heavy metals in surface sediments of the Changhua River estuary and adjacent shelf (Hainan Island). Mar Pollut Bull 76(1):400-405

IGME (2012) Geochemical atlas of Spain (Atlas Geoquímico de España). Instituto Geológico y Minero de España, Madrid In Spanish

Jimenez Ballesta R, Cala V, García R, Patino M (1990) Diferenciación textural en suelos de la cuenca de Madrid. Alteración y génesis mineral. Bol Geol Min 101(3):593-599

Jimenez-Ballesta R, Conde P, Martín JA, García-Giménez R (2010) Pedo-geochemical baseline content levels and soil quality reference values of trace elements in soils from the Mediterranean (Castilla-La Mancha, Spain). Cent Eur J Geosci 2(4):441-454

Malpas J, Duzgoren-Aydin NS, Aydin A (2001) Behaviour of chemical elements during weathering of pyroclastic rocks, Hong Kong. Environ Int 26:359-368

Marcinkonis S, Baltrenaite E, Lazauskas S (2011) Extraction and mapping of soil factors using factor analysis and geostatistical analysis on intensively manured heterogeneous soil in Lithuania. Pol J Environ Stud 20(3):701-708

Martín-Crespo T, Gómez-Ortiz D, Martín-Velázquez S, Esbrí JM, de Ignacio-San José C, Sánchez-García MJ, Montoya-Montes I,
Martín-González F (2015) Abandoned mine tailings in cultural itineraries: Don Quixote route (Spain). Eng Geol 197:82-93

Martínez-Coronado A, Oyarzun R, Esbrí JM, Llanos W, Higueras P (2011) Sampling high to extremely high Hg concentrations at the Cerco de Almadenejos, Almadén mining district (Spain): the old metallurgical precinct (1794 to $1861 \mathrm{AD}$ ) and surrounding areas. J Geochem Explor 109:70-77

Matschullat J, Ottenstein R, Reimann C (1999) Geochemical background - can we calculate it? Environ Geol 39(9):990-1000

Mielke JE (1979) Composition of the earth's crust and distribution of the elements. In: Siegel FR (ed) Review of research on modern problems in geochemistry. UNESCO Report, Paris, pp 13-37

Mihailovic A, Budinski-Peckovic Lj, Popov S, Ninkov J, Vasin J, Ralevic NM, Vucunic Vasic M (2015) Spartial distribution of metal in urban soil of Nivo Sad, Serbia: GIS based approach. J Geochem Explor 150:104-114

Mrvi V, KostiKravljanac L, Cakmak D, Sikiri B, Brebanovi B, Perovi V, Nikoloski M (2011) Pedogeochemical mapping and background limit of trace elements in soils of Branicevo Province (Serbia). J Geochem Explor 109(1):18-25

Palero FJ, Both RA, Arribas A, Boyce AJ, Mangas J, Martin-Izard A (2003) Geology and metallogenic evolution of the polymetallic deposits of the Alcudia Valley mineral field, Eastern Sierra Morena, Spain. Econ Geol 98(3):577-605

Palero FJ, Martin-Izard A, Prieto MZ, Mansilla L (2015) Geological context and plumbotectonic evolution of the giant Almadén mercury deposit. Ore Geol Rev 64(1):71-88

Pillet F (2007) Geografia de Castilla-La Mancha. Biblioteca Añil. Ed. Almud. Castilla - La Mancha

Porta J, López-Acevedo M, Rodríguez M (1986) Técnicas y experimentos en edafología. C.O.I.A.C, Barcelona

Rawlins BG, McGrath SP, Scheib AJ, Breward N, Cave M, Lister TR, Ingham M, Gowing C, Carter S (2012) The advanced soil geochemical atlas of England and Wales. British Geological Survey, Keyworth www.bgs.ac.uk/gbase/advsoilatlasEW.html

Reimann C, Siewers U, Tarvainen T, Bityukova L, Eriksson A, Gilucis V, Gregorauskine V, Lukashev VK, Matinian NN, Pasieczna A (2003) Agricultural soils in northern Europe: a geochemical atlas. Geologisches Jahrbuch. Sonderhefte, Reinhe. ISBN 3-510-95906-X

Reimann C, Filzmoser P, Garrett RG (2005) Background and threshold: critical comparison of methods of determination. Sci Total Environ 346:1-16

Richards LA (1954) Porous plate apparatus for measuring moisture retention and transmission by soil. Soil Sci $66: 105-110$

Roca N, Pazos MS, Bech J (2008) The relationship between WRB soil units and heavy metals content in soils of Catamarca (Argentina). J Geochem Explor 96(2-3):77-85

Rodríguez L, Ruiz E, Alonso-Azcárate J, Rincón J (2009) Heavy metal distribution and chemical speciation in tailings and soils around a $\mathrm{Pb}-\mathrm{Zn}$ mine in Spain. J Environ Manag 90(2):1106-1116

Salminen R, Batista MJ, Bidovec M, Demetriades A, De Vivo B, Lima A (2005) Foregs - Geochemical atlas of Europe. Part 1. Background information, methodology, and maps

Shacklette HT, Boerngen JG (1984) Element concentrations in soils and other surficial materials of the conterminous United States. USGS. Prof. Pap. 1270. U.S. Gov. Print. Office, Washington, D.C

Soil Survey Staff (2006) Keys to soil taxonomy, 10th edn. NRCS. United States Department of Agriculture, Washington DC

Song Y, Choi MS, Lee JY, Jang DJ (2014) Regional background concentrations of heavy metals $(\mathrm{Cr}, \mathrm{Co}, \mathrm{Ni}, \mathrm{Cu}, \mathrm{Zn}, \mathrm{Pb})$ in coastal sediments of the South Sea of Korea. Sci Total Environ 482:80-91

Suh JY, Birch GF (2005) Use of grain-size and elemental normalization in the interpretation of trace metal concentrations in soils of the reclaimed area adjoining Port Jackson, Sydney, Australia. Water Air Soil Pollut 160(1):357-371 
Tack FMG, Verloo MG, Vanmechelen L, Van Ranst E (1997) Baseline concentrations levels of trace elements as a function of clay and organic carbon contents in soils in Flanders (Belgium). Sci Total Environ 201(2):113-123

Torres T, Zapata JL (1986) Paleotopografía y distribución de paleocorrientes de abanicos aluviales de la Depresión Intermedia (Cuenca-Guadalajara). Acta Geológica Hispánica 21(1):55-61

Tume P, Bech J, Reverter F, Bech J, Longan L, Tume L, Sepúlveda B (2011) Concentration and distribution of twelve metal in Central Catalonia surface soils. J Geochem Explor 109(1):92-103

Vera JA (2004) Geología de España. Sociedad Geológica de España and Instituto Geológico y Minero de España. 884 pp.

Vicente MA, Molina E, Espejo R (1991) Clays in paleoweathering processes: study of a typical weathering profile in the
Hercynian basement in the Montes de Toledo (Spain). Clay Miner 26:81-90

Vilas L, de San Jose MA, Garcia-Hidalgo JF, Herranz P, Peláez JR, Perejón A, Gutiérrez Marco JC, Pieren AP, Diez Balda MA et al (1990) Autochthonous sequences. In: Dallmeyer RD, MartínezGarcia E (eds) Pre-Mesozoic geology of Iberia. Springer-Verlag, Berlin

Zhang HB, Luo YM, Wong MH, Zhao QG, Zhang GL (2007) Defining the geochemical baseline: a case of Hong Kong soils. Environ Geol 52(5):843-851

Zhang W, Feng H, Chang J, Qu J, Xie H, Yu L (2009) Heavy metal contamination in surface sediments of Yangtze River intertidal zone: an assessment from different indexes. Environ Pollut 157(5):15331543 